\title{
European Integration and the Clash of Capitalisms: Political Cleavages over Takeover Liberalization
}

\author{
Helen Callaghan and Martin Höpner \\ Max Planck Institute for the Study of Societies, Paulstr. 3, Cologne 50676, Germany. \\ E-mail; hc@mpifg.de, mh@mpifg.de
}

The integration of national markets for corporate control continues to lag behind the removal of barriers to trade in goods and services. To what extent does the protracted political battle over legal harmonization in this area reflect a clash of interests between liberal and coordinated national varieties of capitalism? To find out, we map the distribution of political support for liberal takeover rules within and across countries by analyzing a roll-call vote on the takeover directive in the European Parliament in July 2001. Our data show that, in line with the clash-ofcapitalisms hypothesis, nationality did trump party group position on a left-right axis as a predictor of delegates' attitudes toward takeover regulation. Given the increasing interference of European Union-level legislative initiatives with the regulatory pillars of coordinated market economies, and the accession of 10 new Eastern European member states, we expect the salience of the clash-of-capitalisms cleavage to increase in the near future.

Comparative European Politics (2005) 3, 307-332. doi:10.1057/palgrave.cep.6110061

Keywords: comparative political economy; European integration; varieties of capitalism; corporate governance; takeover regulation

\section{Introduction}

European Commission efforts to create a unified European market for corporate control stretch back more than 30 years. The European Union (EU) takeover directive that passed in December 2003 is a far cry from this ambition. After decades of negotiation, member states agreed to disagree on the legality of anti-takeover defenses. At 20 years after the Commission's white book on the completion of the internal market, the EU remains a non-integrated economic area of different national varieties of corporate governance.

Our analysis of the political issues at stake draws out two distinct lines of conflict pertaining to takeover regulation: A 'class conflict', because active markets for corporate control have distributional implications inside firms by securing benefits for shareholders at the expense of employees, and a "clash of capitalisms', because the benefits and costs of a unified European takeover regime are distributed unevenly across EU member states depending on the nature of national corporate governance arrangements prior to harmonization. 
A comment by Internal Market Commissioner Frits Bolkestein made no secret of the fact that both effects were intended. In November 2002, the Commissioner explained that

'[the trade unions] cling to traditional rights as though these were valid for ever, regardless of economic conditions. They want to remain within the comfortable and secure boundaries of what has been referred to as the Rhenish model of capitalism, where stakeholders are pampered instead of shareholders, and where consultations take place on numerous round tables. However, if Europe really wants to become the most competitive and most modern economic area, it must leave the comfortable setting of the Rhenish model and subject itself to the harsher conditions of the Anglo-Saxon form of capitalism, where the rewards, but also the risks, are higher' (Bolkestein, 2002).

Which of these conflicts is more salient in political struggles over the European Commission's efforts to create a single European market for corporate control? To answer this question, we constructed a data set based on a 2001 roll-call vote on the takeover directive in the European Parliament and tested competing hypotheses by applying a binary logit model. Specifically, we investigate whether members of the European Parliament vote according to their party group affiliation, as the literature on European party systems would suggest, or whether nationality was a stronger predictor of voting behavior, as on might expect from research in the varieties of capitalism tradition.

We find, first, that the relative importance of nationality and party group affiliation varied systematically depending on the party group in question. Intra-group cohesion was strong among the small left-wing, green, liberal and right-wing party groups. By contrast, the large center-right and center-left party groups were both split down the middle along national lines. Second, and more importantly, the overall magnitude of support for the takeover directive varied dramatically across countries. At the extremes, more than 90 percent of all German delegates voted against the directive, while more than 90 percent of British delegates voted in favor.

Our findings imply that persistent variation in corporate governance rules across EU member states is not just a result of incremental differences in the partisan composition of national governments. Instead, we observe a 'clash-ofcapitalisms' alignment with broad cross-party alliances within countries defending their respective national variety of corporate governance. Several large- $n$ studies on cleavage lines in the European Parliament have shown that the partisan divide tends to dominate over the national divide. Our analytical framework provides a starting point for the systematic analysis and explanation of cases that deviate from the dominant pattern. 
In view of the increasing interference of EU-level legislative initiatives with the regulatory pillars of coordinated market economies, and the accession of 10 new Eastern European member states, we expect the salience of the clash-ofcapitalisms cleavage to increase in the near future.

\section{History of the EU Takeover Directive}

The first effort to harmonize takeover rules across EU member states dates back to the early 1970s, when the European Commission appointed Robert Pennington, a law professor at Birmingham University, to present a report on takeover regulations in the European Community. The Pennington Report on Takeover Offers and Other Offers, ${ }^{1}$ presented in November 1973, was accompanied by a draft directive. Like later drafts, the content of the Pennington directive was strongly influenced by the UK City Code. It was abandoned after several years of informal discussion due to limited interest among member states. Instead, the Commission contented itself with issuing a voluntary code in form of the 1977 Recommendation on Securities Transactions (Johnston 1980, 183).

In the mid-1980s, the drive towards completion of the internal market and a surge in large-scale controversial takeover battles brought takeover legislation back onto the agenda (Berglöf and Burkart, 2003). A draft directive presented in 1989 was mainly concerned with assuring a transparent market and eliminating speculative abuses. It drew strong British criticism for failing to address the problem of cross-national differences in barriers to takeovers. Responding to British pressures, Internal Market Commissioner Martin Bangemann in May 1990 presented a communication to the Council of Ministers, which outlined supplementary measures aimed at curtailing defenses against hostile bids. Rather than launching a new directive to deal with these anti-takeover defences, the Commission offered suggestions for amending three existing company law proposals, including the draft takeover directive. ${ }^{2}$ With these suggestions, the Commission lined up firmly with the advocates of an open market for corporate control. It asserted that

'[t]akeover bids may be viewed in a positive light in that they encourage the selection by market forces of the most competitive companies and the restructuring of European companies which is indispensable to meet international competition' (cited in Holmes and de Bony, 1990).

The amended version of the takeover directive, presented in September 1990, was dropped the following year because no qualified majority could be found in the Council of Ministers (Europolitique, 1991; Dauner Lieb and Lamandini, 2002, 1-2). 
At the 1994 European Council in Essen, the Commission announced its intention to draw up a new proposal and launched consultations on the issue. The resulting draft directive, presented in 1996 and revised in 1997, covered broadly the same ground as the previous proposal, albeit in less detail. Unlike the 1989 and 1990 versions of the directive, which would have imposed very detailed rules on member states, the new proposal was for a 'framework' directive, which established the same general principles to govern the conduct of takeovers as the previous proposal, but no longer included detailed provisions as to how these principles should be implemented. However, the directive did include a neutrality rule preventing the board of a target company from taking defensive measures without authorization by the general meeting of shareholders (European Commission, 1996). An amended version of the 1996 draft, presented in November 1997, further tightened the neutrality requirement by placing a ban on pre-bid authorization of defensive measures. Any authorization by the general meeting of shareholders for the adoption of defensive measures would have to be granted during the period of the bid.

In June 1999, the Internal Market Council reached political agreement on a revised version of the 1997 text, except on the question regarding the appropriate authority for takeover bids in Gibraltar. The neutrality rule of the 1997 version was maintained, but as a concession to opponents of the neutrality rule, the board of a target company was allowed to increase the share capital during the bid acceptance period if its general shareholder assembly had approved the capital augmentation up to 18 months prior to the bid (European Commission, 1997). A year later, in June 2000, the Gibraltar matter was resolved and the Council of Ministers endorsed the directive and submitted it to the European Parliament for approval. In December, the European Parliament, mobilized by its German Christian Democrat Rapporteur, voiced major objections to the Council proposal (see Dauner Lieb and Lamandini, 2002 , 2). A conciliation procedure was launched, but on July 4, 2001, the text prepared by the conciliation committee was rejected in the European Parliament by the narrowest possible margin: There were 273 votes in favor and 273 votes against. In all, 22 delegates abstained (European Report, 2001).

After the failure of the 2001 directive, the European Commission appointed a High-Level Group of Experts to examine the objections raised by opponents and to propose solutions. This group, chaired by law professor Jaap Winter, delivered a report in January 2002 (see European Report, 2002). In October of the same year, the Commission presented a new draft directive, which incorporated some of the Winter group proposals. Among the innovations was a so-called breakthrough rule ${ }^{3}$ (article 11 ), which suspended voting caps and restrictions on the transfer of securities for the duration of the bid. The new directive immediately came under fire from German members of the European Parliament because the new breakthrough rule did not encompass multiple 
voting rights. The German government insisted that a takeover directive should either rule out all defence mechanisms, including multiple voting rights, or none (Guerrera and Jennen, 2003).

Amending the directive proved difficult because the French and Scandinavian governments, who had supported the previous version of the directive, refused to accept a directive depriving their companies of double or multiple voting rights. The Commission spent several months trying to find a solution acceptable to a qualified majority of member states (see Beffa et al., 2003). To this end, it attempted to isolate the Scandinavian countries by suggesting that multiple shareholding structures should be included in the list of corporate defense mechanisms to be outlawed by the directive, but that double voting rights should be exempt. ${ }^{4}{ }^{5}$ The tactic of gaining French support for article 11 failed due to Germany's insistence that French double voting rights must be included.

By May, a majority of member states was ready to adopt a minimal version of the directive excluding both the neutrality rule (article 9) and the breakthrough rule (article 11), but Frits Bolkestein, the Internal Market Commissioner, threatened to veto this proposal, thereby forcing the Council to reach a unanimous position to over-ride the Commission's veto. Bolkestein even suggested withdrawing the Commission's proposals altogether, but this move was not supported by other members of the Commission (EIU, 2003; SZ, 2003).

On November 27, after months of intensive bargaining, the Council found a compromise solution leaving each member state to decide for itself whether or not to require companies incorporated within its territory to apply the neutrality rule (article 9) and/or the breakthrough rule (article 11). Where member states refrain from requiring companies to adopt these rules, they must allow companies to adopt them voluntarily. However, member states may implement a reciprocity clause to exempt companies that apply the neutrality rule and/or the breakthrough rule from applying these rules if they become the subject of an offer launched by a company that does not apply the same rule.

The compromise was unanimously endorsed by the Council, approved by the European Parliament on December 16 and formally adopted by the Council on December 22, 2003. In the eyes of Internal Market Commissioner Bolkestein, the final version of the directive was 'not worth the paper it is written on' (cited in Jennen, 2003). Bolkestein was disappointed that an ambitious liberalizing harmonization project had been turned into a compromise, which, by and large, allows national varieties of corporate governance to remain intact. Advocates of more extensive European takeover legislation immediately called for fresh measures from the Commission, but Bolkestein declared that he had 'no desire' to see another proposal until the 5 -year review clause inserted into the directive was up (European Report, 2003). 


\section{What was at Stake?}

The stated aim of the Commission's legislative initiative was not merely to integrate European markets in order to 'strengthen the legal certainty of crossborder takeover bids in the interest of all concerned' and 'ensure protection for minority shareholders' but also to undertake 'harmonization conducive to corporate restructuring' (Commission, 2002, 3). In other words, the goal was not a common legal framework per se, but the realization of a substantive vision regarding the nature of this framework. The Commission wanted the integrated European market for corporate control to be an active one. The level playing field was to be achieved by removing rather than adding barriers to takeovers.

The idea that promoting hostile bids will enhance company performance derives from microeconomic theories of 'moral hazard problems' in principalagent relationships (Jensen and Meckling, 1976; Fama, 1980; Shleifer and Vishny, 1997). The managers of a large corporation are typically not its owners. As their interests diverge from those of owners, managers cannot always be relied upon to maximize shareholder value. This problem is said to be particularly acute in firms with diffuse ownership, because shareholders who hold only a minute fraction of a company have little incentive to spend time monitoring managers (Berle and Means, 1932).

Exposure to takeover threats is said to mitigate moral hazard problems by improving managerial incentives to maximize shareholder value (Manne, 1965). Firms performing below potential are attractive takeover targets. Hostile bidders can make money by taking control and improving shareholder value orientation. Incumbent managers risk losing their job in the event of a hostile takeover. According to the theory, the threat of a hostile takeover therefore provides an incentive for managers to maximize shareholder value.

To ensure adequate exposure to takeover threats, managers need to be prevented from interfering with hostile bids. Otherwise, they may be tempted to undertake value-reducing activities that make them more difficult to dismiss or that make the company less attractive to the bidder. For example, they could diversify into product lines in which they have specialized knowledge or purchase assets in one of the markets in which the raider operates, in order to create a high combined market share and thereby create anti-trust problems (Hay and Morris, 1991, 519; Edlin and Stiglitz, 1995). The neutrality rule purports to provide a solution to this problem by increasing the supervision of agents by their principals during the period of a bid.

The many caveats to this simple microeconomic theory ${ }^{6}$ barely entered the political discourses on the directive. Neither supporters nor opponents questioned its efficacy in redistributing power to shareholders. Instead, 
disagreement revolved mainly around whether this was desirable. Two separate distributional considerations were relevant here: First, active markets for corporate control have distributional implications inside firms by securing benefits for shareholders at the expense of employees. Second, due to different national starting points, the benefits and costs of a unified market for corporate control are distributed unevenly across EU member states.

\section{'Class conflict': Distributional implications inside firms}

Gains made by shareholders of target companies in takeover bids tend to accrue from redistribution rather than efficiency gain (Shleifer and Vishny, 1988; Deakin and Slinger, 1997, 124; Cook and Deakin, 1999, 28). This follows from the fact that non-value maximizing managerial behavior largely consists of transferring corporate wealth from shareholders to other non-management constituencies such as employees, suppliers and customers. Examples of redistributive consequences of increased shareholder value orientation are wage decreases, job cuts or the removal of assets from employee pension funds (Shleifer and Summers, 1988). Empirically, a comparison of how net surplus value was distributed among labor, capital suppliers and governments for the 100 largest European companies between 1991 and 1994 shows that companies in countries with active markets for corporate control tend to pay higher dividends, while companies in countries without hostile takeovers pay a higher part of net value added in wages (de Jong, 1997, 17f).

Besides shifting material resources towards shareholders, active markets for corporate control also shift decision-making powers within the firm. Mergers and friendly takeovers are preceded by negotiations that leave scope for employee participation in the decision-making process. By contrast, hostile takeover offers by definition are addressed directly to shareholders, bypassing the stakeholders of the target company. Managers and workers of the target company may be informed or even consulted, but they have no say in the final decision.

\section{'Clash of capitalisms': Asymmetric impact of the directive on liberal and coordinated market economies ${ }^{7}$}

The benefits and costs of promoting active markets for corporate control are distributed unevenly not only within firms but also across countries. Potential takeover targets are distributed unevenly across countries because exposure to takeover threats affects the structure and strategies of companies in ways that determine their attractiveness to hostile bidders. Strong pressures to maximize shareholder value prevent firms from growing beyond the point at which the marginal returns on equity diminish (de Jong, 1996). In the absence of takeover 
threats, managers can pursue strategies other than maximizing marginal return on equity. For example, they can absorb higher labor costs, avoid layoffs during cyclical downturns or cross-subsidize unprofitable branches of the company.

The profitability gap does not mean that investors in German companies are worse off than investors in British companies. Höpner and Jackson (2001) show that investors in both countries obtain comparable returns on equity. ${ }^{8}$ German companies generate lower earnings per share, but this is compensated for by lower share prices. Market value relative to turnover is more than four times higher in Britain than in Germany. Market value relative to the number of employees is more than six times higher in the UK.

However, the 'low profits - low price' equilibrium - the typical feature of corporate governance systems in coordinated market economies - is not sustainable under an open market for corporate control. 'Underperforming' companies are attractive targets for hostile bidders, who can earn a one-time takeover premium by increasing the company's profitability by shifting resources from stakeholders to shareholders. Moreover, lower relative market valuations make corporations vulnerable to takeovers through share swaps. Corporations with higher market valuations can use their shares as a currency to give premiums to shareholders of the target firm.

The above suggests that in a common European market for corporate control, potential takeover targets will initially be distributed unevenly across countries. Due to long-standing cross-national differences in the level of legal and non-legal takeover barriers, companies' prior exposure to takeover threats varies dramatically across EU member states. ${ }^{9}$ Potential targets are likely to be concentrated in countries whose companies have had limited prior exposure to takeover threats, while more potential bidders are likely to come from countries where active markets for corporate control are already established.

A second reason to expect a clash-of-capitalisms cleavage is provided by research in the varieties of capitalism tradition. By exposing their previously sheltered companies to takeover threats, coordinated market economies sacrifice 'comparative institutional advantages' in product niches where firms from liberal market economies are not competitive. Exposure to takeover threats contravenes production strategies that rely extensively on long-term and relationship-specific investment (Streeck, 1991). Firms pursuing such strategies are concentrated in countries that have so far been sheltered from takeovers (Hall and Soskice, 2001).

Takeover threats discourage long-term and non-transferable investment under conditions of asymmetric information or contractual imperfections. Managers under pressure to satisfy footloose investors at any point in time have an incentive to increase the short-term stock market valuation of their 
companies by raising dividends at the expense of productivity-enhancing investments whose value is difficult to assess from the outside. ${ }^{10}$ Workers and suppliers have insufficient incentives to acquire specialist skills or equipment that are of little value outside the firm that employs them, if they do not expect the relationship with that particular firm to last beyond the short term. ${ }^{11}$ The threat of contract termination, which increases with greater exposure to takeover threats, reduces incentives to incur relationship-specific investments (Shleifer and Summers, 1988).

The detrimental effects of active markets for corporate control on long-term and relationship-specific investment are more disconcerting for some countries than others, because firms pursuing production strategies that rely on these types of investment only prosper in countries where hostile takeovers are rare.

In sum, analysis of the political issues at stake reveals two distinct lines of conflict. First, active markets for corporate control have distributional implications inside firms by securing benefits for shareholders at the expense of employees. Second, due to different national starting points, the benefits and costs of a unified market for corporate control are distributed unevenly across EU member states.

\section{Research Question and Hypotheses}

Which of these considerations was more salient in the political struggle over the directive, which ultimately transformed a far-reaching liberalizing harmonization into a guarantee for the persistence of different national takeover regimes? A priori, a plausible case can be made for both the 'class conflict' view and the clash-of-capitalisms view.

Party group cohesion across national borders might be expected because of the distributional implications inside firms of an active market for corporate control. Comparative research on political parties has shown that party programs, strategies and policy outcomes broadly reflect the interests of the parties' respective socioeconomic clienteles (Hibbs, 1977, 1992; Alt, 1985; Budge and Robertson, 1987; Alvarez et al., 1991; Hicks and Swank, 1992; Schmidt, 2002; Wilensky, 2002). The further to the left a political party, the more it should lean towards workers in distributional struggles between workers and shareholders. As discussed above, the promotion of active markets for corporate control - a key aim of the directive - benefits shareholders at the expense of employees. Opposition to the directive should therefore be stronger among left-leaning parties than among parties on the right. Given that European party groups consist of delegates from national parties with broadly comparable ideological positions on a left-right axis, one could expect delegates within party groups to vote together irrespective of nationality. 
316

An additional reason for left-right cleavages over takeover regulation may be the structural and functional linkages between corporate governance and other institutional domains of production regimes (Boyer, 1998; Aoki, 2001; Hall and Soskice, 2001; Streeck, 2001; Amable, 2004). Research in the varieties of capitalism tradition finds institutional complementarities between industrial relations systems and corporate governance systems, in the sense that coordination in one sphere facilitates coordination in the other sphere. Coordinated wage bargaining systems contribute to a relatively egalitarian income distribution by preventing wage dispersion (Mosher, 2002). To the extent that wage bargaining coordination depends on weakly developed markets for corporate control, left-leaning parties and their clienteles have an additional reason to oppose the directive.

The competing hypothesis, whereby nationality should trump party group affiliation as a predictor of voting behavior can be made plausible in the light of the asymmetric impact of the takeover directive across EU member states. As explained above, countries starting from a status quo of high barriers to takeovers have more companies attractive to hostile bidders or pursuing production strategies that are contravened by takeover threats than countries where active markets for corporate control are a long-standing feature. Regardless of their views on the distributional conflict within firms, delegates should be reluctant to endorse initiatives that undermine the comparative institutional advantages that firms in their home country enjoy (Hall and Soskice, 2001, 52). Given differences in production strategies between liberal and coordinated market economies, one might therefore expect delegates from coordinated market economies to be less inclined to support the directive.

We use the roll-call vote over the 2001 version of the directive to assess the relative saliency of these considerations because it provides unique, quasiexperimental conditions for the observation of attitudes towards European takeover liberalization. First, as with all roll-call votes in the European Parliament, delegates from all relevant political parties in all member states had to reveal and record their preferences at the same time. Second, the 2001 version of the proposal was a relatively far-reaching harmonization attempt. This makes it more suitable for our purposes than the 2003 compromise version, which could be disliked either because it was still too ambitious or because it was not ambitious enough. Third, it was widely anticipated that the 2001 result would be a close call, leaving little scope for symbolic voting. In the event, it turned out to be one of the rare occasions where literally every vote counted. Fourth, we have no reason to believe that there were package deals linking the directive to other legislative initiatives, which would render the delegates' votes worthless as an indicator of attitudes toward takeover regulation. 


\section{Dependent and independent variables}

We use a binary logit model to predict the voting behavior of each delegate, given her scores on the independent variables discussed below. Our dependent variable is a dummy variable that equals $I$ if a given delegate voted 'yes' in the roll-call vote on the takeover directive in July 2001, and zero otherwise. In 2001, the European Parliament had 626 members from 15 member states. Of these, 568 were present at the roll-call vote. Our data set is based on the results of the vote as reported in the Official Journal of the European Communities (OJ, 2002).

The first independent variable is a categorical variable indicating the delegate's party group affiliation. In 2001, delegates to the European Parliament organized into eight party groups. We coded them from left to right as follows: 0 for the Confederal Group of the European United Left/Nordic Green Left (GUE/NGL); 1 for the Group of the Greens/European Free Alliance (Verts/ALE); 2 for the Group of the Party of European Socialists (PSE); 3 for the Group of the European People's Party (Christian Democrats and European Democrats) (PPE-DE); 4 for the Group of the European Liberal, Democrat and Reformist Party (ELDR); and 5 for the Union for the Europe of the Nations Group (UEN). The Technical Group of Independent Members (TDI) was not coded, because this group consisted of members without party affiliation and was set up for the sole purpose of providing access to the benefits of group status. ${ }^{12}$ The Group for a Europe of Democracies and Diversities (EDD) was not coded either, because the main programmatic commitment of the group - anti-Europeanism - does not warrant the expectation that affiliated members share broadly similar attitudes on socioeconomic issues.

The second independent variable, La Porta et al.-Index, approximates the distance of the directive from the status quo on takeover regulation in the delegate's home country. As explained above, countries starting from a status quo of low shareholder orientation have more companies attractive to hostile bidders or pursuing production strategies that are incompatible with takeover threats than countries where active markets for corporate control have long forced companies to focus on shareholder value. As a proxy for the shareholder orientation of the corporate governance system, we use the La Porta et al.-Index of shareholder protection ${ }^{13,14}$ (La Porta et al., 1998). This ordinal index ranges from 0 to 6 , where 0 indicates very low protection of shareholder interests (Belgium), while 6 indicates very high shareholder protection. The highest score among countries in our sample is 5 (UK). ${ }^{15}$

The third independent variable, government/opposition, controls for the possibility that support for the directive is systematically higher among delegates from parties with government responsibility in their home countries 
(Hix, 2001, 673). Governing parties are directly represented in the Council of Ministers. Unlike opposition parties, they thus have some influence on shaping the directives before they are presented to the European Parliament for ratification. To control for the possibility that this affects attitudes toward the directive, we use a binary variable that takes on the value 1 when the subgroup is in government at the national level and the value 0 when the subgroup is in opposition at home.

The fourth independent variable, country size, controls for the possibility that support for the directive is systematically higher among delegates from large countries. Important pieces of EU legislation are sometimes informally hammered out by the governments of large member states, with small member states complaining about being excluded from the bargaining table. To control for the possibility that large member states had a disproportional influence on the design of the takeover directive, and that this influenced attitudes toward the final version, we include the size of the delegate's home country, measured in terms of population in 2001.

The fifth independent variable, economic growth, controls for the possibility that delegates' attitudes toward takeover regulation are influenced by the economic dynamism of their home country. Companies in expanding economies may be more interested in a takeover-facilitating framework than companies in stagnating economies. We therefore include GDP growth in the home country of the subgroup over the 5 years prior to the vote, that is, between 1995 and 2000 . This control variable takes values from 9.01 percent (Germany) to 41.01 percent for the Irish economy, which was expanding enormously during the 1990s.

\section{Results}

The coefficients of the logit regression on delegates' voting decision are reported in Table 1 below. All independent variables are significant at the 0.01 level in all models. Model 2 has the best-fit statistics, with McFadden's pseudo$R^{2}=0.4041$.

As always with non-linear binary regression models, the estimated parameters do not provide directly useful information for understanding the relationship between the independent variables and the outcome. ${ }^{16}$ The logit coefficients capture the change in the log odds for a unit change in the independent variable, but this has very little substantive meaning. A simple non-linear transformation allows for the following more intuitive interpretation of effects in terms of changes of the odds: A unit move to the right on the party group affiliation index increases the odds of voting 'yes' by between 172 and 260 percent, depending on the model. Likewise, for each one-step increase in the La Porta et al.-Index score of the delegate's home country, the 
Table 1 Coefficients of the logit regressions on delegates' voting decision (dependent variable: dummy variable $=1$ if the delegate supported the takeover directive in the roll-call vote on July 4, 2001, zero otherwise ${ }^{a}$ )

\begin{tabular}{|c|c|c|c|c|c|}
\hline Variable & Expectation & Model 1 & Model 2 & Model 3 & Model 4 \\
\hline Party group affiliation ${ }^{b}$ & + & $\begin{array}{c}1.235(8.48)^{* * *} \\
{[244.0 \%]}\end{array}$ & $\begin{array}{c}1.281(8.41)^{* * * *} \\
{[260.2 \%]}\end{array}$ & $\begin{array}{c}1.002(7.97)^{* * *} \\
{[172.5 \%]}\end{array}$ & \\
\hline La Porta et al.-Index ${ }^{\mathrm{c}}$ & + & $\begin{array}{c}1.037(10.77)^{* * *} \\
{[182.2 \%]}\end{array}$ & $\begin{array}{l}1.286(10.04)^{* * *} \\
{[261.8 . \%]}\end{array}$ & & $\begin{array}{c}1.002(9.92)^{* * *} \\
{[172.3 \%]}\end{array}$ \\
\hline Government/opposition $^{d}$ & + & & $\begin{array}{c}0.7355(2.94)^{* * *} \\
{[108.6 \%]}\end{array}$ & $\begin{array}{c}0.5533(2.62)^{* * *} \\
{[73.9 \%]}\end{array}$ & $\begin{array}{c}0.6675(3.07)^{* * *} \\
{[94.9 \%]}\end{array}$ \\
\hline GDP growth $1995-2000^{f}$ & + & & $-0.1172(-3.44)^{* * *}$ & $0.1908(5.25)^{* * *}$ & $-0.0771(-2.92)^{* * *}$ \\
\hline Constant & & $-5.863(-11.03)^{* * *}$ & $\begin{array}{c}{[-11.1 \%]} \\
-4.178(-5.39)^{* * *}\end{array}$ & $\begin{array}{c}{[21.0 \%]} \\
-5.893(-6.72)^{* * *}\end{array}$ & $\begin{array}{c}{[-7.4 \%]} \\
-0.9778(-1.93)^{* * *}\end{array}$ \\
\hline$N$ & & 520 & 520 & 520 & 520 \\
\hline $\operatorname{LR} \chi^{2}$ & & 258.9 & 290.50 & 141.72 & 174.87 \\
\hline Pseudo- $R^{2^{g}}$ & & 0.3602 & 0.4041 & 0.1971 & 0.2432 \\
\hline
\end{tabular}

Absolute value of $z$ statistics in parentheses. ${ }^{* * *} P<0.01 ; * * P<0.05 ;{ }^{*} P<0.1$.

Percentage change in the odds ratio for a unit change in the independent variable in square brackets.

Software: STATA 8.

${ }^{a}$ Source: Data set constructed by the authors on the basis of the EP roll-call vote results reported in OJ (2002).

$\mathrm{b}_{0}=\mathrm{GUE} / \mathrm{NGL} ; 1=$ Verts ALE; $2=\mathrm{PSE} ; 3=\mathrm{PPE}-\mathrm{DE} ; 4=\mathrm{ELDR} ; 5=\mathrm{UEN}$. TDI, EDD and NI were excluded from the analysis (see text).

'Source: La Porta et al. (1998). Luxembourg is not coded by La Porta et al. and was therefore excluded from the analysis.

${ }^{\mathrm{d}}$ Dummy variable $=1$ if the delegate's party is in government at the national level, zero otherwise.

National residents in 2001 (millions). Source: Fischer Weltalmanach.

Source: OECD Main Economic Indicators.

${ }^{8}$ We use McFadden's $R^{2}$. 
odds of the delegate voting 'yes' increase by between 182 and 262 percent, depending on the model. If the delegate's party is in government at the national level, the odds of the delegate voting 'yes' increase by between 74 and 109 percent. However, when looking at these results, it is essential to bear in mind that a constant factor change in the odds does not correspond to a constant change or a constant factor change in the probability. ${ }^{17}$

To arrive at a substantively meaningful interpretation, we compute the predicted probabilities of a delegate voting 'yes' for all possible combinations of party affiliation and home country score on the La Porta et al.-Index, holding the control variables constant at their mean. ${ }^{18}$ The results are reported in Table 2.

Table 2 shows that the further to the left a delegate's party group was on the left-right axis, and the less shareholder oriented her home country was prior to passage of the directive, the less likely it is that the delegate supported the directive. For example, the probability that a member of the far-left GUE/ NGL from a country scoring 0 on the La Porta et al.-Index voted 'yes' was 0.0013 . For a member of the far-right UEN from the same country, the probability was 0.4353 . These results suggest that EU parliamentarians are indeed agents with two principals (cf. Hix, 2002) who face a loyalty conflict when the ideological position of their transnational party group regarding the distributional struggle within firms clashes with the 'national interest' of their home country.

A closer look at the data reveals that this loyalty conflict is resolved differently depending on the party group in question. Table 3 displays the percentage of delegates who voted 'yes' on the takeover directive in the roll-call vote of July 4, 2001, sorted by country and party group affiliation. It shows systematic differences in the relative importance of national and party group affiliation.

Table 2 Predicted Probabilities of delegates' support for the directive

\begin{tabular}{lcccccr}
\hline Party & \multicolumn{7}{l}{ La Porta index score of the delegate's home country } \\
\cline { 2 - 7 } & 0 & 1 & 2 & 3 & 4 & 5 \\
\hline GUE/NGL & 0.0013 & 0.0046 & 0.0164 & 0.0568 & 0.1790 & 0.4410 \\
Verts/ALE & 0.0046 & 0.0163 & 0.0566 & 0.1783 & 0.4398 & 0.7397 \\
PSE & 0.0162 & 0.0563 & 0.1776 & 0.4387 & 0.7388 & 0.9110 \\
PPE-DE & 0.0561 & 0.1770 & 0.4376 & 0.7379 & 0.9106 & 0.9736 \\
ELDR & 0.1763 & 0.4364 & 0.7370 & 0.9102 & 0.9735 & 0.9925 \\
UEN & 0.4353 & 0.7361 & 0.9099 & 0.9733 & 0.9925 & 0.9979 \\
\hline
\end{tabular}

Logit predicted probabilities of the delegate voting 'yes' for all categories of the two explanatory variables, holding the three control variables constant at their mean. Software: STATA 8. 
Table 3 Number of delegates who voted yes/no on the takeover directive in the roll-call vote of July 4, 2001, sorted by country and party group affiliation

PPE-DE PSE ELDR Verts/ALE GUE/NGL UEN TDI EDD NI Total

Yes No Yes No Yes No Yes No Yes No Yes No Yes No Yes No Yes No

\begin{tabular}{lrrrrrrrrrrrrrrrrrrrrr}
\hline Austria & 0 & 6 & 0 & 7 & & 0 & 1 & & & & & & & & & 4 & 0 & 18 \\
Belgium & 0 & 6 & 0 & 3 & 5 & 0 & 0 & 5 & & & & & 0 & 1 & & & & & 20 \\
Denmark & 1 & 0 & 3 & 0 & 5 & 0 & & & 0 & 0 & 1 & 0 & & & 3 & 0 & & & 13 \\
Finland & 3 & 1 & 3 & 0 & 4 & 0 & 1 & 0 & 0 & 1 & & & & & & & & & 13 \\
France & 15 & 4 & 16 & 4 & & & 0 & 9 & 0 & 9 & 3 & 0 & 0 & 0 & 6 & 0 & 5 & 0 & 71 \\
Germany & 1 & 51 & 0 & 34 & & & 0 & 5 & 0 & 5 & & & & & & & & & 96 \\
Greece & 1 & 8 & 2 & 7 & & & & & 0 & 6 & & & & & & & & & 24 \\
Ireland & 4 & 1 & 1 & 0 & 1 & 0 & 0 & 1 & & & 4 & 0 & & & & & & & 12 \\
Italy & 3 & 29 & 12 & 0 & 4 & 0 & 0 & 0 & 1 & 4 & 6 & 0 & 7 & 3 & & & & & 69 \\
Luxembourg & 2 & 0 & 2 & 0 & 1 & 0 & 0 & 1 & & & & & & & & & & 6 \\
Netherlands & 0 & 9 & 1 & 6 & 7 & 0 & 0 & 4 & 0 & 1 & & & & & 0 & 3 & & & 31 \\
Portugal & 9 & 0 & 8 & 1 & & & & & 0 & 0 & 2 & 0 & & & & & & & 20 \\
Spain & 20 & 4 & 0 & 22 & 3 & 0 & 3 & 1 & 0 & 4 & & & & & & & 0 & 0 & 57 \\
Sweden & 7 & 0 & 5 & 0 & 4 & 0 & 2 & 0 & 0 & 0 & & & & & & & & & 18 \\
UK & 33 & 0 & 27 & 0 & 10 & 0 & 2 & 4 & & & & & & & 0 & 2 & 0 & 0 & 78 \\
Total & 99 & 119 & 80 & 84 & 44 & 0 & 8 & 31 & 1 & 30 & 16 & 0 & 7 & 4 & 9 & 5 & 9 & 0 & 546 \\
\% ${ }^{a}$ & 44 & 54 & 49 & 51 & 100 & 0 & 20 & 76 & 3 & 79 & 100 & 0 & 44 & 25 & 53 & 29 & 90 & 0 & 96 \\
\hline
\end{tabular}

Source: Data set constructed by the authors on the basis of the EP roll-call vote results reported in the Offical Journal of the European Communities (OJ, 2002).

${ }^{\text {a}}$ Percentage voting yes [no] of all party group members who voted, including those who abstained.

Intra-group cohesion was strong among the left-wing, green, liberal and right-wing party blocks. Members of the affiliated parties voted together regardless of their nationality. All delegates affiliated with the liberal ELDR and the rightist UEN supported the directive, while only 3 percent of left-wing GUE/NLG members and 20 percent of the green Verts/ALE party group voted in favor. By contrast, the center-right and center-left party groups were both split down the middle, with nationality serving as a strong predictor of voting behavior. In all, 49 percent of PSE members and 44 percent of PPE-DE members voted yes, while 51 percent of PSE members and 54 percent of PPE$\mathrm{DE}$ delegates voted no. Moreover, in 13 of the 15 member states, the overwhelming majorities of Socialist and Christian Democrat/Conservative party group members voted together across party group lines. This suggests that considerations related to their nationality did have a strong influence on the voting behavior of these delegates.

This pattern is presented graphically in Figures 1 and 2. Overall, there is a strong correlation between party group position on a left/right axis and the percentage of party group members voting yes, but is important to note that 


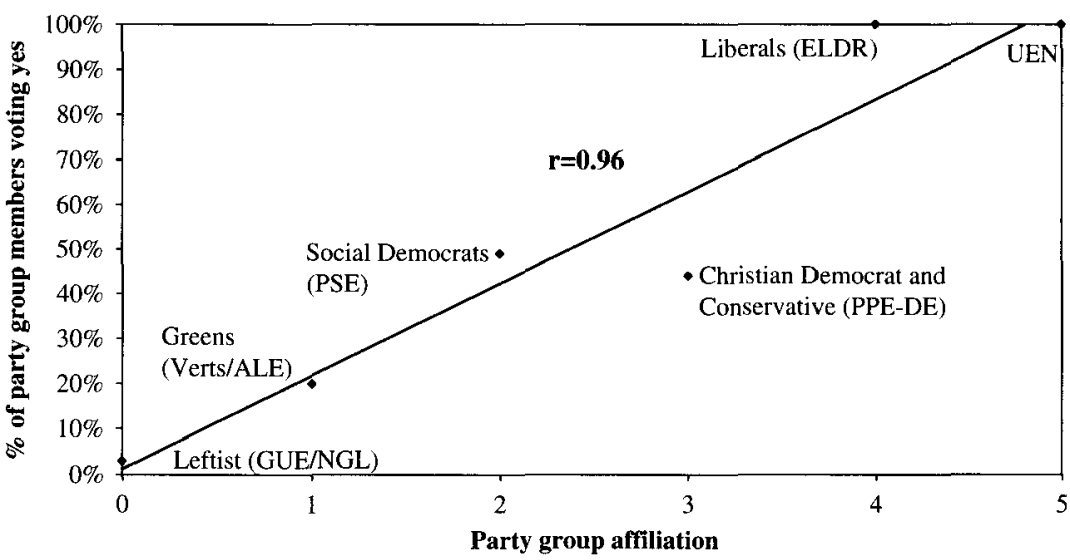

Figure 1 Party group affiliation and percentage of party group members supporting the directive.

there is no discernable difference in the voting behavior of delegates affiliated with center-left (PSE) and center-right (PPE-DE) party groups (see Figure 1).

In all countries except Spain, Italy and France, more than 80 percent of delegates from center-right and center-left parties voted together across party lines (see Table 3 above). Given that 65 percent of all delegates belong to either the PSE or the PPE-DE groups, this means that for most delegates, considerations related to their party group affiliation were not the dominant influence on voting behavior. Figure 3 shows that the overall percentage of delegates supporting the directive varies dramatically across countries, ranging from 1 percent in Germany to more than 90 percent in Denmark and the UK.

In sum, whether nationality or party group affiliation was the stronger determinant of voting behavior depends on the party group in question. Intragroup cohesion was strong among the left-wing, green, liberal and right-wing party blocks. By contrast, the larger center-right (PPE-DE) and center-left party blocks (PSE) were both internally divided, with nationality serving as a strong predictor of voting behavior.

\section{What explains the observed pattern?}

Why did overall support for the directive vary so dramatically across countries? As discussed above, one possible explanation could be the asymmetric economic impact of the directive on different member states, depending on the degree of investor protection prior to passage of the directive. The data displayed in Figure 3 is broadly compatible with this hypothesis. In Belgium, Italy, Germany, Greece, the Netherlands and Austria, where shareholder 


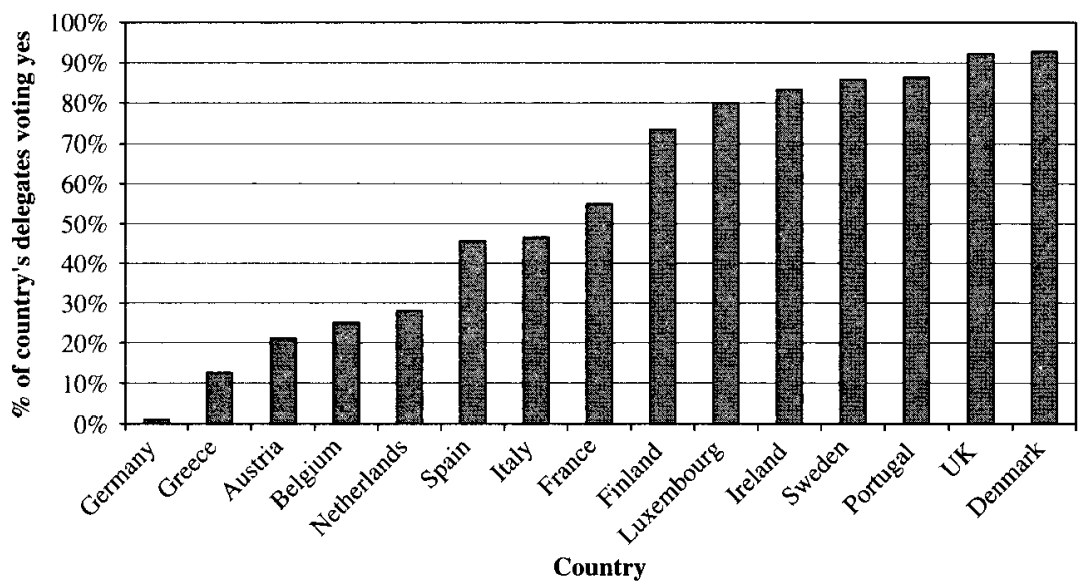

Figure 2 Overall percentage of delegates from each country who supported the directive.

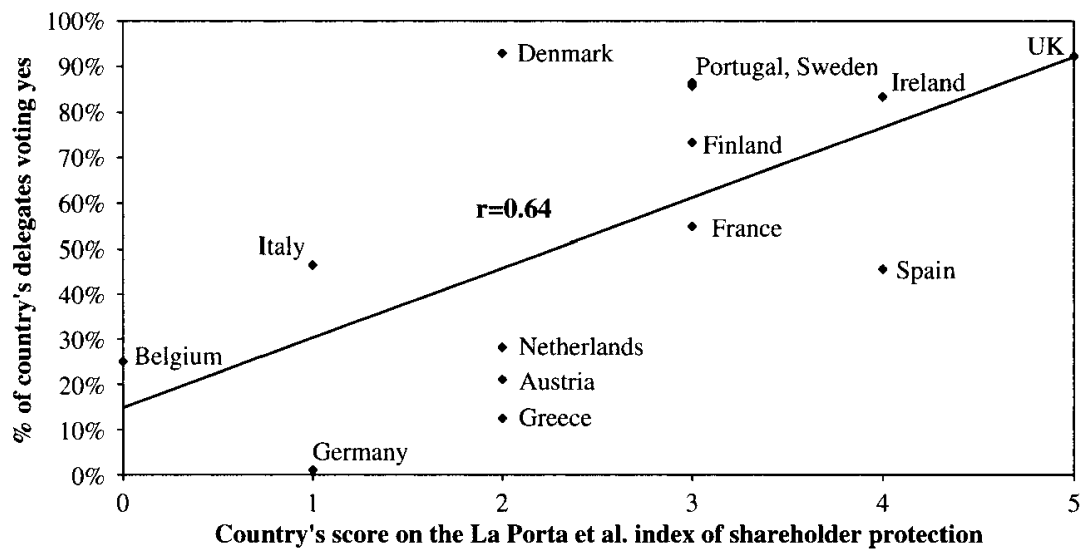

Figure 3 Shareholder orientation of national corporate governance system and percentage of delegates supporting the directive.

protection is below average, less than 30 percent of all delegates supported the directive. In Finland, Portugal, Sweden, Ireland and the UK, where shareholder protection is relatively strong, more than 70 percent of all delegates voted in favor. This may seem surprising in the cases of Finland and Sweden, where high levels of employment protection indicate broad political support for the protection of employee interests, even though investor protection and market capitalization are above average. Redistribution from 
workers to shareholders occurs when a corporate governance system moves from a 'low profitability-low share price' equilibrium to higher profitability and share price valuation. In the Nordic countries, where the transition to a relatively capital market oriented position has already occurred, even Social Democratic parties may see no reason for opposing investor-oriented corporate governance features.

Why does the strength of nationality as a predictor of voting behavior vary so dramatically across party groups? One possible explanation is the commitment of non-centrist delegates to clearly defined transnational ideologies. The ideologies of liberal and left-wing parties are hard to square with 'varieties of capitalism' conceptions of national interest. Liberals distrust the efficacy of non-market forms of coordination. For them, the economic dislocation caused by a dismantling of takeover barriers does not contravene the national interest of coordinated market economies. Rather, they see it as a necessary evil on the way towards a purer form of capitalism, which they regard as superior. Left-wing parties in liberal market economies are likely to care more about maintaining solidarity with their comrades abroad than about ensuring optimal economic performance of their particular variety of capitalism. Centrist party groups have less overarching ideological commitments. Instead, they often compete for the median vote in their home countries. As a result, the position of centrist parties regarding the distributional conflict between shareholders and stakeholders should diverge within party groups if the position of the median voter diverges across countries. ${ }^{19}$ This explanation begs the question why the median voter in liberal systems is to the right of the median voter in coordinated economies. Our discussion of the divergent national interests of different varieties of corporate governance provides one possible explanation.

Alternatively, greater cohesion of the smaller parties might be due to the fact that their degree of national fractionalization was lower. Three of the seven countries with below average scores on the La Porta et al.-Index (Germany, Austria and Greece) did not have any delegates affiliated with the liberal (ELDR) and rightist (UEN) party groups, and two of the seven countries with above average scores on the La Porta et al.-Index (Ireland and the UK) did not have any delegates affiliated with the leftist GUE/NGL party group.

\section{Implications and outlook}

The most interesting aspects of our data are the degree and partisan composition of support for the directive in different EU member states. By itself, it is hardly surprising that the majority of politicians from countries with weak shareholder orientation wants to preserve weak shareholder orientation, while the majority of politicians from countries with strong shareholder 
protection wants to preserve strong shareholder orientation. If it were otherwise, those same majorities would change their domestic corporate governance system. Countries with weak shareholder orientation would become countries with strong shareholder orientation if this were the preference of a political majority. What is remarkable is the magnitude of cross-country variation in support for the directive. At the extremes, more than 90 percent of all British delegates voted yes, while more than 90 percent of German delegates voted no. ${ }^{20}$

The magnitude of cross-country variation in political support for the directive is relevant to the emerging literature on the political underpinnings of different corporate governance systems (e.g. Gourevitch and Shinn, forthcoming; Pagano and Volpin, forthcoming; Roe, 2003). It shows that persistent variation in corporate governance rules across EU member states is not just a result of incremental differences in the partisan composition of national governments. Contrary to models of the European policy process as a multilevel game, opposition parties in coordinated and liberal market economies did not try to use EU legislation as a means of altering the domestic status quo. Instead, they joined broad cross-party alliances to defend their respective national models against EU encroachment.

The partisan composition of support for the takeover directive is interesting because the observed voting pattern is unusual in several ways. First, largescale analyses of roll-call votes in the European Parliament have established that, in general, delegates vote along transnational party lines more than national lines (Kreppel and Tsebelis, 1999; Noury, 2002; Hix et al., 2005). In the takeover case, nationality trumps party group affiliation as a predictor of voting behavior. Second, the large centrist party groups (PSE and EPP) are generally among the most internally cohesive groups in the European parliament (Hix et al., 2005). In the takeover case, both of them were split down the middle. Third, we find clear differences in the relative influence of nationality and party group affiliation depending on the party group in question. While the implications to be drawn from a single outlier case for the study of voting patterns in general is obviously limited, our analysis thus provides a starting point for further research. For example, it might be worthwhile comparing the roll-call vote on the takeover directive with roll-call votes on other pieces of legislation to see whether similar patterns prevail. The exhaustive data set of pre-2001 EP roll-call votes compiled by Hix et al. (2005) should lend itself well to such endeavors.

We suspect that, due to the onset of a new phase of European integration, the salience of the clash-of-capitalisms cleavage line might even increase in the future. Compared to more recent ambitions, the creation of a common market for goods and services was a relatively harmless project. The removal of barriers to trade in goods and services enhances competition between 
member states without dictating the means by which competitiveness is achieved. It leaves scope for the coexistence of different varieties of capitalism. By contrast, legal harmonization in many other areas, including the regulation of takeovers and other aspects of corporate governance, must inevitably interfere with the internal organization of either coordinated or liberal market economies. It seems likely that the increasingly interventionist nature of European integration will lead to a rise in the number of political battles fought by cross-party coalitions defending their respective varieties of capitalism. $^{21}$

Our findings also provide a better basis for speculation about the future prospects for law-driven convergence of EU member states in the area of takeover regulation. First, widespread intra-national cross-party consensus suggests that radical takeover law reforms at the domestic level in the wake of party alternation in government are unlikely in the near future. Second, the next attempt to rid European markets for corporate control of their takeover barriers will require ratification by an enlarged European Parliament that includes delegates from 10 new member states from Central and Eastern Europe, who joined the EU in May 2004. Our analysis suggests that resistance to the creation of a level playing field devoid of takeover barriers is to be expected from delegates on the far left everywhere and from centrist delegates from countries with a status quo of weak shareholder orientation. Conversely, support for liberalization efforts is to be expected from centrist delegates from countries with a status quo of strong shareholder orientation, and from liberal and far-right delegates everywhere. So far, the new member states from Central and Eastern Europe have not developed liquid capital markets. Their systems of corporate control rely on bank monitoring rather than on arms-length monitoring through capital markets (Mallin and Jelic, 2000). It is therefore to be expected that Eastern enlargement will swell the ranks of opponents to takeover liberalization, at least in the short term.

In the short-run, market-driven convergence is equally unlikely. The takeover directive passed in 2003 contains a clause that requires member states to allow their companies to adopt the controversial articles 9 and 11 on a voluntary basis. Proponents of the clause are hoping that market mechanisms will achieve the level playing field which politicians refused to legislate. The idea is that companies unwilling to adopt the neutrality rule or the breakthrough rule will be penalized with lower market valuations. However, previous experience with voluntary codes casts some doubt over the efficacy of this mechanism. In Germany, a voluntary codex pertaining to investor protection in takeover situations, drawn up in 1995, was ignored by about half of all German listed companies. Pressure from stock markets or shareholder assemblies was evidently too weak to force companies into voluntary submission. 
This is not to say that divergence will persist forever, or that no changes have occurred to date. Our analysis focused on an attempt to radically change national varieties of corporate governance. In a process of path-dependent transition, the corporate governance systems of all continental European countries are already moving towards Anglo-American practices (Lannoo, 1999; Deeg and Perez, 2000; Groenewegen, 2000; Melis, 2000; Bieling and Steinhilber, 2002; Beyer and Höpner, 2003; Höpner, 2003; O'Sullivan, 2003; Rose and Mejer, 2003). This is true both for developments at the company level in the direction of stronger shareholder value orientation and for reforms initiated by national legislators to strengthen shareholder protection and dismantle legal barriers to hostile bids. In November 2004, European member states agreed to oblige all listed European corporations to publish balance sheets according to the International Financial Reporting Standards (IFRS). ${ }^{22}$ The gradual convergence of European varieties of corporate governance is caused primarily by the rise of institutional investors and the internationalization of their investment portfolios, combined with growing demands for stock market capital in Continental Europe. These developments are gradually changing the balance of attitudes towards shareholder primacy and will eventually facilitate further European harmonization of takeover rules. However, the pace of convergence is still low. Our analysis has shown that many countries still have a long way to go before the tipping point is reached. The increasingly interventionist nature of European integration and the accession of 10 new Eastern European member states provide further reasons to expect that the battle over the takeover directive was not the last clash of capitalisms.

\section{Acknowledgments}

We thank Andreas Broscheid, Peter Gourevitch, Peter Hall, Torben Iversen, David Soskice, Wolfgang Streeck and two anonymous referees for helpful comments and suggestions.

\section{Notes}

1 Comm. Doc. XI/56/74.

2 The other directives were the 2 nd and 5 th company law directives. For details, see Holmes and de Bony (1990).

3 The purpose of a breakthrough rule is to prevent situations where a bidder owning a substantial amount of the risk-bearing capital of a company cannot exercise control due to deviations from the one-share-one-vote principle. It facilitates the success of hostile bids by ensuring that acquiring a majority stake is sufficient for a takeover.

4 Technically, it would have been possible to outvote the Nordic countries in the Council of Ministers, even though there was a reluctance to do so because of worries concerning Sweden's pending decision on the introduction of the Euro (FAZ, 2003).

5 Guerrera and Williamson (2003) and Blum (2003). 
6 It is not clear that takeover threats really provide adequate incentives for management to maximize shareholder value. Hostile takeovers are only a threatening prospect if managers have to fear job loss without adequate financial compensation and difficulties in finding comparable positions in the future. Financial compensation clauses - so-called 'goiden parachutes' - and managerial job mobility reduce the effectiveness of takeover threats. Moreover, takeover threats can only improve management incentives to maximize shareholder value if hostile bidders primarily target underperforming companies. In reality, there are many other plausible motives for takeover bids, including the fortification of management entrenchment in the bidding company, remuneration, diversification or the elimination of competitors (see Jenkinson and Mayer, 1992). Strong financial performance is not sufficient to stave off takeover threats in the latter situations, and might even be counterproductive. For a review of empirical evidence on whether takeovers promote shareholder value, see Cook \& Deakin (1999).

7 We use the term as defined by Hall and Soskice (2001): coordinated market economies are production regimes in which managers strategically coordinate their actions with stakeholders and other firms.

8 Comparing indicators of corporate performance for the 19 largest British and 20 largest German industrial firms belonging to the 'Europa 500', Höpner and Jackson (2001) show that price-earnings ratios and dividend yields are quite similar in both countries.

9 Between 1988 and 1998, 220 hostile takeover attempts were announced in Britain. By contrast, only 20 were announced in France, 12 in Sweden and five in Germany (Schneper and Guillén, 2003, 4).

10 In a world of perfect information, the price of a share should accurately reflect future payments to which the share gives title. Any cuts in productivity-enhancing investment would lead to an instant drop in the share price by reducing the company's net present value. In reality, the value of investments in research and development, human capital, cooperative labor relations or reputation may be difficult to assess without inside knowledge of the company (see, e.g. Stein, 1988).

11 In a world of perfect contracts, workers and suppliers could ensure financial compensation in the event of premature contract termination. In reality, contracts may be implicit and therefore not legally enforceable.

12 The European Court has since decided to withdraw group status from the TDI because its members lacked a shared program.

13 Fulfillment of the following criteria contributes to a high score on the La Porta et al. -Index: the country allows shareholders to mail their proxy votes to the firm; shareholders are not required to deposit their shares prior to the general shareholders' meeting; cumulative voting or proportional representation of minorities on the board of directors is allowed; an oppressed minorities mechanism is in place; the minimum percentage of share capital that entitles a shareholder to call for an extraordinary shareholders' meeting is less or equal to 10 percent; and shareholders have preemptive rights that can only be waived by a shareholder's vote. For further details, see La Porta et al. (1998).

14 Shareholder protection is one of several dimensions distinguishing different varieties of capitalism; the La Porta et al.-Index is one of the measures used by Hall and Gingerich (2004) in the construction of their index of overall strategic coordination in industrialized countries. The La Porta et al-Index on shareholder protection and Hall and Gingerich's index are therefore highly correlated (Pearson's $r=-0.77$ ). However, the La Porta et al-Index does not measure complementarities with other features of production regimes, such as employment protection, etc.

15 Luxemburg is not covered by the La Porta et al. -Index.

16 See Long and Freese (2001). 
17 For example, if the odds double from 1:100 to $2: 100$, the probability increases only by approximately 0.01 . If the odds are $1: 1$ and double to $1: 2$, the probability increases by 0.167 .

18 For details regarding this computation, see Long and Freese (2001).

19 For example, the German SPD and British Labour are both affiliated with the PSE (and therefore have index number 2 in our analysis), while German CDU and British Conservatives are both affiliated with the EPP (and therefore have index number 3). However, one could argue that both German parties are to the left of both British parties, so that a more accurate indexation would assign index number 2 to both SPD and CDU and index number 3 to Labour and Conservatives.

20 For more details on the politics of takeover regulation in Germany and the UK, see Callaghan (2004), Cioffi (2002) and Höpner and Jackson (2001).

21 Chirac's and Schröder's recent protests against 'ultra-liberalism' in the context of the services directive may be an example. What unites the neo-Gaullist French President and the SocialDemocratic German Chancellor is not a shared party ideology, but rather a common interest in defending their national variety of capitalism against the spread of rules inspired by the AngloSaxon model.

22 Although European accounting does not cause redistributive measures comparable to the 2001 takeover directive proposal, we find a similar clash-of-capitalisms pattern in the struggle over IFRS. Belgium, Italy, France and Spain demanded factoring out the IAS 39 rules, while United Kingdom, Sweden and Denmark opposed this.

\section{References}

Alt, J.E. (1985) 'Political parties, world demand, and unemployment. Domestic and international sources of economic activity', American Political Science Review 79(4): 1016-1040.

Alvarez, M.R., Garrett, G. and Lange, P. (1991) 'Government partisanship, labor organization, and macroeconomic performance', American Political Science Review 85(3): 539-556.

Amable, B. (2004) The Diversity of Modern Capitalism, Oxford: Oxford University Press.

Aoki, M. (2001) Toward a Comparative Institutional Analysis, Cambridge, MA: MIT Press.

Beffa, J.-L., Langenlach, L. and Touffut, J.-P. (2003) 'Levelling the Playing Field or Queering the Pitch? How to interpret the takeover directive', Prisme du Centre Cournot pour la Recherche en Economie 1, November 2003.

Berglöf, E. and Burkart, M. (2003) 'European takeover regulation', Economic Policy 18(1): 171-213.

Berle, A. and Means, G. (1932) The Modern Corporation and Private Property, New York: Macmillan.

Beyer, J. and Höpner, M. (2003) 'Corporate governance and the disintegration of organised capitalism in the 1990s', West European Politics 26(4): 179-198.

Bieling, H.-J. and Steinhilber, J. (2002) 'Finanzmarktintegration und Corporate Governance in der Europäischen Union', Zeitschrift für Internationale Beziehungen 9(1): 39-74.

Blum, P. (2003) 'Compromise sought on voting rights in EU', Financial News (Daily), March 23, 2003.

Bolkestein, F. (2002) 'Zeitfragen', Neue Züricher Zeitung, November 9, 2002.

Boyer, R. (1998) 'Hybridization and Models of Production: Geography, History, and Theory', in R. Boyer, E. Charron, U. Jürgens and S. Tolliday (eds.) Between Imitation and Inovation. The Transfer and Hybridization of Productive Models in the International Automobile Industry, Oxford: Oxford University Press, pp. 23-56.

Budge, I. and Robertson, D. (1987) 'Comparative Analysis of Post-War Election Programs: Do Parties Differ and How?', in I. Budge, D. Robertson and D. Herl (eds.) Ideology, Strategy and 
Party Change: Spatial Analysis of Post-War Election Programs in 19 Democracies, Cambridge: Cambridge University Press, pp. 23-56.

Callaghan, H. (2004) 'The domestic politics of EU legislation - British, French and German attitudes towards takeover regulation, 1985-2003 Conference of Europeanists, Chicago, March $11-13,2004$.

Cioffi, J. (2002) 'Control, transparency, and the politics of company and takeover law reform in Germany and the European Union 13th International Conference of Europeanists, Chicago, March 14-16, 2002.

Commission (2002) 'Communication on the proposal for a directive of the European Parliament and of the Council on takeover bids', Commission of the European Communities, October 2, 2002.

Cook, J. and Deakin, S. (1999) 'Stakeholding and corporate governance: Theory and evidence on economic performance, Discussion Paper, ESRC Centre for Business Research, University of Cambridge.

Dauner Lieb, B. and Lamandini, M. (2002) 'The new proposal of a directive on company law concerning takeover bids and the achievement of a level playing field', Report Commissioned by the Committee on Legal Affairs and the Internal Market of the European Parliament, December 2002.

de Jong, H.W. (1996) 'European capitalism between freedom and social justice', in W. Bratton, J. A. MacCahery, S. Picciotto and C. Scott (eds.) International Regulatory Competition and Coordination, Oxford: Clarendon Press, 538pp.

de Jong, H.W. (1997) 'The governance structure and performance of large European corporations', The Journal of Management and Governance 1: 5-27.

Deakin, S. and Slinger, G. (1997) 'Hostile takeovers, corporate law, and the theory of the firm', Journal of Law and Society 24(1): 124-151.

Deeg, R. and Perez, S.A. (2000) 'International capital mobility and domestic institutions: Corporate finance and governance in four European cases', Governance 13(2): 119-153.

Edlin, A.S. and Stiglitz, J.E. (1995) 'Discouraging rivals: Managerial rent seeking and economic insufficiencies', American Economic Review 85(5): 1301-1312.

EIU (2003) 'Takeover fudge', Economist Intelligence Unit, December 3, 2003 (Wednesday).

European Commission (1996) 'Press release: Streamlined proposal for takeovers directive', RAPID, February 7, 1996.

European Commission (1997) 'Press release: Company law: Amended proposal for a directive on takeover bids', RAPID, November 20, 1997.

European Report (2001) 'Eleventh hour deal on the takeover directive clinched', European Report, No. 2599.

European Report (2002) 'High Level Group presents first takeover bids report', European Report, No. 2650, January 12, 2002.

European Report (2003) 'MEPs give the thumbs-up to Council's takeover bids text', European Report, No. 2829, December 17, 2003.

Europolitique (1991) 'Accords et desaccords sur la directive sur les OPA', Europolitique, No. 1666, April 6, 1991.

Fama, E. (1980) 'Agency problems and the theory of the firm', Journal of Political Economy 88(2): 288-307.

FAZ (2003) 'Kompromißangebote im EU-Übernahmerecht', Frankfurter Allgemeine Zeitung, April $11,2003,15 \mathrm{pp}$.

Gourevitch, P. and Shinn, J. (2005) Political Power and Corporate Control. The New Global Politics of Corporate Government, Princeton, NJ: Princeton University Press.

Groenewegen, J. (2000) 'European integration and changing corporate governance structures: The case of France', Journal of Economic Issues 34(2): 471-479. 
Guerrera, F. and Jennen, B. (2003) 'UK in deal with Germany over takeover code', Financial Times, February 3, 2003 (Monday), 10pp.

Guerrera, F. and Williamson, H. (2003) 'EU open to redrafting of takeover directive', Financial Times, February 15, 2003, 9pp.

Hall, P. and Soskice, D. (eds.) (2001) Varieties of Capitalism: The Institutional Foundations of Comparative Advantage, Oxford: Oxford University Press.

Hall, P.A. and Gingerich, D.W. (2004) 'Varieties of capitalism and institutional complementarities in the political economy: An empirical analysis', Misc: MPIfG Discussion Paper, 04 (5).

Hay, D. and Morris, D.J. (1991) Industrial Economics and Organization: Theory and Evidence, Oxford: Oxford University Press.

Hibbs, D. (1977) 'Political parties and macroeconomic policies', American Political Science Review 71(4): 1467-1487.

Hibbs, D. (1992) 'Partisan theory after fifteen years', European Journal of Political Economy 8(3): 361-373.

Hicks, A.M. and Swank, D.H. (1992) 'Politics, institutions, and welfare spending in industrialized democracies 1960-1982', American Political Science Review 86(3): 658-674.

Hix, S. (2001) 'Legislative behavior and party competition in the European Parliament: An application of nominate to the EU', Journal of Common Market Studies 39(4): 663-688.

Hix, S. (2002) 'Parliamentary behaviour with two principals: Preferences, parties, and voting in the European Parliament', American Journal of Policial Science 46(4): 688-698.

Hix, S., Noury, A. and Roland, G. (2005) 'Power to the parties: Cohesion and competition in the European Parliament', British Journal of Political Science 34(4): 767-793.

Holmes, G. and de Bony, E. (1990) 'EC commission trains its guns on corporate takeover defenses', $M \& A$ Europe, May/June, 1990, 35pp.

Höpner, M. (2003) 'European corporate governance reform and the German party paradox', Misc: MPIfG Discussion Paper, 03(4).

Höpner, M. and Jackson, G. (2001) 'An emerging market for corporate control? The Mannesmann takeover and German corporate governance', Misc: MPIfG Discussion Paper, 01 (4).

Jenkinson, T. and Mayer, C. (1992) 'The assessment: Corporate governance and corporate control', Oxford Review of Economic Policy 8(3): 1-10.

Jennen, B. (2003) 'Auf deutsches Betreiben zementiert die EU protektionistische Übernahmeregeln', Financial Times Deutschland, December 17, 2003, 30pp.

Jensen, M.C. and Meckling, W. (1976) 'Theory of the firm: Managerial behavior, agency costs and ownership structure', Journal of Financial Economics 3(4): 305-360.

Johnston, A. (1980) The City Takeover Code, Oxford: Oxford University Press.

Kreppel, A. and Tsebelis, G. (1999) 'Coalition formation in the European Parliament', Comparative Political Studies 32(8): 933-966.

La Porta, R., Lopez-de-Silanes, F., Shleifer, A. and Vishny, R. (1998) 'Law and finance', Journal of Political Economy 106(6): 1113-1155.

Lannoo, K. (1999) 'A European perspective on corporate governance', Journal of Common Market Studies 37(2): 269-294.

Long, S.J. and Freese, J. (2001) Regression Models for Categorical Dependent Variables Using Stata, College Station: Stata Press.

Mallin, C. and Jelic, R. (2000) 'Developments in corporate governance in Central and Eastern Europe', Corporate Governance 8(1): 43-51.

Manne, H. (1965) 'Mergers and the market for corporate control', Journal of Political Economy 73(2): 110-120.

Melis, A. (2000) 'Corporate governance in Italy', Corporate Governance 8(4): 347-355.

Mosher, J. (2002) 'Distributional struggle in labor unions 13th International Conference of Europeanists', Chicago, IL, March 14-16, 2002. 
Noury, A. (2002) 'Ideology, nationality and Euro-Parliamentarians', European Union Politics 3(1): $33-58$.

OJ (2002) 'Result of roll call votes: Lehne report A5-0237/2001', Official Journal of the European Communities C65E: 70-71.

O'Sullivan, M. (2003) 'The political economy of comparative corporate governance', Review of International Political Economy 10(1): 23-72.

Pagano, M. and Volpin, P. (forthcoming) 'The political economy of corporate governance', American Economic Review.

Roe, M.J. (2003) Political Determinants of Corporate Governance - Political Context, Corporate Impact, Oxford and New York: Oxford University Press.

Rose, C. and Mejer, C. (2003) 'The Danish corporate governance system: From stakeholder orientation towards shareholder value', Corporate Governance 11(4): 335-344.

Schmidt, M.G. (2002) 'The Impact of Political Parties, Constitutional Structures and Veto Players in Public Policy', in H. Keman (ed.) Comparative Democratic Politics, London: Sage, pp. 166-184.

Schneper, W.D. and Guillén, M. (2003) 'Stakeholder rights and corporate governance: A crossnational study of hostile takeovers', Manuscript, December 2003 version (submitted to Administrative Science Quarterly).

Shleifer, A. and Summers, L.H. (1988) 'Breach of Trust in Hostile Takeovers', in A.J. Auerbach (ed.) Corporate Takeovers: Causes and Consequences, Chicago, IL: University of Chicago Press, pp. 33-68.

Shleifer, A. and Vishny, R. (1988) 'Value maximization and the acquisition process', Journal of Economic Perspectives 2(1): 7-20.

Shleifer, A. and Vishny, R. (1997) 'A survey of corporate governance', Journal of Finance 52(2): $737-783$.

Stein, J.C. (1988) 'Takeover threats and managerial myopia', The Journal of Political Economy 96(1): $61-80$.

Streeck, W. (1991) 'On the Institutional Conditions of Diversified Quality Production', in E. Matzner and W. Streeck (eds.) Beyond Keynesianism: The Socioeconomics of Production and Full Employment, Brookfield, VT: Edward Elgar, pp. 21-61.

Streeck, W. (2001) 'Introduction: Explorations into the Origins of Non-Liberal Capitalism in Germany and Japan', in W. Streeck and K. Yamamura (eds.) The Origins of Nonliberal Capitalism: Germany and Japan, Ithaca: Cornell University Press.

SZ (2003) 'Brüssel droht Vorschlag für Übernahme-Richtlinie zu kippen', Süddeutsche Zeitung, November 24, 2003, $21 \mathrm{pp}$.

Wilensky, H. (2002) Rich Democracies. Political Economy, Public Policy, and Performance, Berkeley: University of California Press. 